\title{
The PESTEL Model Application to Ok Boomer and TikTok from a Public Relations Perspective
}

\author{
Assoc. Prof. Young Joon LIM, PhD \\ Department of Communication \\ University of Texas Rio Grande Valley, Edinburg, United States of America \\ E-mail: young.lim@utrgv.edu
}

\begin{abstract}
This article explores the macro-environmental (external business environment) factors of the Ok Boomer generation and their use of TikTok, based on the PESTEL model. The six key factors of the model (political, economic, social, technological, environmental, and legal) guide this article to analyze the overnight popularity of the term Ok Boomer and the integration of millennials and Generation $Z$ into the Ok Boomer generation. This article also demonstrates why and how TikTok has risen to a powerful social media platform for brands in association with $\mathrm{OK}$ Boomers. Finally, this article provides public relations practitioners with the comprehensive information on the Ok Boomer generation and their alliance with TikTok, so they can plan strategic operations to capture the interest of young consumers.
\end{abstract}

Keywords: Ok Boomers; TikTok; PESTEL model; Macro-environmental factors; Public relations strategy. 


\section{Introduction}

The Gen Z-generated phrase "Ok Boomer" originated on social media platform TikTok to mock condescendingly closed-old mindedness. The phrase went viral and was acknowledged by the American public in October 2019 when the New York Times, the Washington Post, and major television outlets such as NBC, CBS, and CNN picked up the Ok Boomer virality in the national news (see sources from references). As social media plays the dominant role in communication for young people, new words and phrases created in the social media community are characterized by online dictionaries at a rapid pace. For example, Dictionary.com defines "Ok Boomer" as "a viral internet slang phrase used, often in a humorous or ironic manner, to call out or dismiss out-of-touch or close-minded opinions associated with the Baby Boomer generation and older people more generally" (2020). The phrase had been discussed in the public sphere during late 2019, and it has become popularized as the conceptual term, which introduces the Ok Boomer generation, as opposed to the Baby Boomer generation. According to Dimock (2019), the term OK Boomer as a noun cluster embraces two specific group of people: millennials (born 1981-1996) and Generation Z (born 1997-2012).

Young people use the term $O K$ Boomer to encounter old people who offer judgmental and narrow-minded condescension dressed up as wisdom (Roberts, 2019). As a result, the Ok Boomer generation represents those who express their disappointment and frustration against baby boomers who have taken advantage of American boomer socialism that financially supports three federal programs such as Medicare, Social Security, and mortgage-interest deduction, exclusively designed for old people. Rather than making a direct and repulsive speech at the Baby Boomer generation, Ok Boomers reveals their criticism in collective mockery via online meme posts on TikTok. Although the term Ok Boomer can be regarded as a derogatory phrase against baby boomers, the Ok Boomer generation has emerged as a new America's political and social force in 2020. Departing from the PESTEL model, one of the public relations management theories, this article explores a wide range of current Ok Boomer phenomena in the United States. In particular, this article focuses on analyzing the effects of the Ok Boomer generation and their favorite social media platform TikTok from a public relations perspective. It is hoped that this article provides public relations practitioners with comprehensive information on the Ok Boomer generation, so they can plan strategic operations to capture the interest of young target audience.

\section{Literature Review}

The PESTEL model serves as a concept or a framework in marketing and public relations management. It is used to evaluate the macro-environmental (external business environment) factors that have an impact on a company, an industry, or 
an organization. The model paves the way for a wide survey of the whole marketing situation from the various angles, in which the organization focuses on monitoring the whole public relations environment while contemplating corporate plans or developing business strategies (Song, Sun, \& Jin, 2017). Such angles are derived from political, economic, social, technological, environmental, and legal factors of the external business environment. In other words, the PESTEL model is the acronym of the six factors, which incorporate the comprehensive framework of business threats and opportunities into situational assessment for future business strategies. In the fields of public relations and marketing, it is important to evaluate the macro-environment for the organization before any kind of tactical plan is implemented. The evaluation, based on the PESTEL model, can function as the key to differentiating from the competition and to forming competitive business strategies. Therefore, the PESTEL model can be summarized as a management function that can help the organization assess major external factors that positively or negatively affect its operation in the market (Kenton, 2020). Stuiver et al. (2016) argued that organizations use the PESTEL model to plan sustainable marketing innovation and nurture long-term objectivities. Since it originated from the name ETPS by Harvard professor Francis J. Aguilar's 1967 book "Scanning the Business Environment," scholars throughout the years have developed the pragmatic framework, including external factors of demographics, ethics, ecology, and psychographics. Those factors are used as a means of situational analysis for business evaluation purposes, but the evaluation of the external business environment has rather been complicated because of the comprehensive strategies for online and offline business practice (Hassan, Jailani, \& Rahim, 2014). Departing from such a complication, this article employees the factors of PESTEL as the major analytic tool. The PESTEL model can eloquently guide this article to examine what is happening in the broader digital marketing or e-business environment where opportunities and potential risks co-exist with uncertain external aspects. Below is the detailed discussion for each factor of PESTEL model, including Figure 1, which illustrates core examples of factors for this article:

\section{Political Factors}

These factors determine if a government influenced the economy, how, and to what degree. Government policies through legislation and enforcement have huge impacts on business performance. For example, organizations are vulnerable to changes in political stability, tax policies, trade tariffs, labor and environmental laws, and consumer protection regulations. These are all politically imposed, motivated, or structured by the government's intervention in the economy. As political or politically motivated factors affect the way organizations operate business, these political factors require organizations be prepared for agile responses to the present and future governmental policies for a better adjustment in their marketing operations accordingly (Shiu, Hassan, \& Walsh, 2009; Njinyah, 2018). 


\section{Economic Factors}

However profitable or influential, an organization can rely on economic factors that directly affect the organization's long-term existence. Economic factors are strongly correlated with current forces of economic trends, growth rates, interest rates, inflation, taxation, unemployment rates, monetary policies, and disposable income of consumers and businesses. On occasion, these factors are categorized into micro-economic and macro-economic factors. The former heavily depends on how much consumers can spend on products or services, whereas the latter is affected by governmental controls over economic policies such as interest rates and taxation. More importantly, all economic factors are intertwined with the fundamental economic mechanism of demand/ supply curve model. For example, a rise in sales taxes can reduce the total amount of consumer purchases, and it leads to a decrease in the demand of consumer commodities. As a result, the way companies price their products or services is affected.

\section{Social Factors}

These factors relate to the social environment of the market, especially from the cultural perspective, which include basic human livelihood such as demographics, psychographics, cultural trends, public health, and social aspects. Social factors are deeply related to the understanding of what people think and how they behave in what motivations or opinions. All trends of lifestyle, religion, family issues, and general cultural affairs can affect how organizations plan market strategies and analyze the pattern of consumer buying behavior. In fact, steady growth of population as a fundamental component among the factors motivates organizations to set social and cultural long-term marketing plans.

\section{Technological Factors}

These factors change fast, adapting to quick innovations in technology. New infrastructures of technology and communication play a leading role in impacting the way organizations provide and distribute products or services to consumers, who are better informed by new media platforms. In particular, new communication technology serves as the main tool for organizations to customize specific messages or information for the target audience. To enhance application of new technology to business operation, organizations pay attention to what innovations and technological advancements are available in the market, in addition to making more investment in market research and innovation.

\section{Environmental Factors}

These factors might have become considered essential since the beginning of the $21^{\text {st }}$ century as natural resources are scarce, air pollution gets worse, and global temperatures rise. In short, environmental factors include all those that influence 
or are determined by the surrounding environment on earth. In lieu of the rise of consumer's demand for ethical business operations, organizations are pressured to come up with environment-friendly solutions for reducing carbon footprint and increasing sustainable business practices. Since more younger consumers blame industrial organizations for the climate change and environmental pollution, practicing business as an ethical and sustainable organization is heavily associated with the creation of positive corporate images and reputation. As a result, highlighting organizational support for clean and renewable energy from sustainable resources remains a strategic practice of business.

\section{Legal Factors}

A wide range of laws belong to legal factors that affect the business environment. Since legislation varies from laws of health safety, consumer rights, trade to labor, organizations protect themselves from committing any illegal operations. They stay current with present and future legal changes in any nations they practice business. It is critical to stay informed for global organizations in terms of recognizing different or complex regulations, codes, and laws in certain countries. Maintaining legitimate business practices in any territories is a necessity to avoid legal attacks from across all domestic and global markets (Sanders, 2011; Wiersum, Lescuyer, Nketiah, Wit, \& Wiersum, 2013).

The PESTEL model has been applied to identify the key macro-economic factors, which influence the practice of marketing and business. Regardless of the industry sector, the macro-economic environment of the digital age has provided any organization with opportunities and risks. Before the major rise of digital age, organizations were more concerned about regulations, restrictions, and policies, enforced by the government. However, new communication technology of social media has added more factors of new concerns and strategies to organizations. While consumers are informed more than enough about organizational performance through social media, their use of social media shows different layers of generations, in which U.S. social demographics are categorized as: The Baby Boomer generation

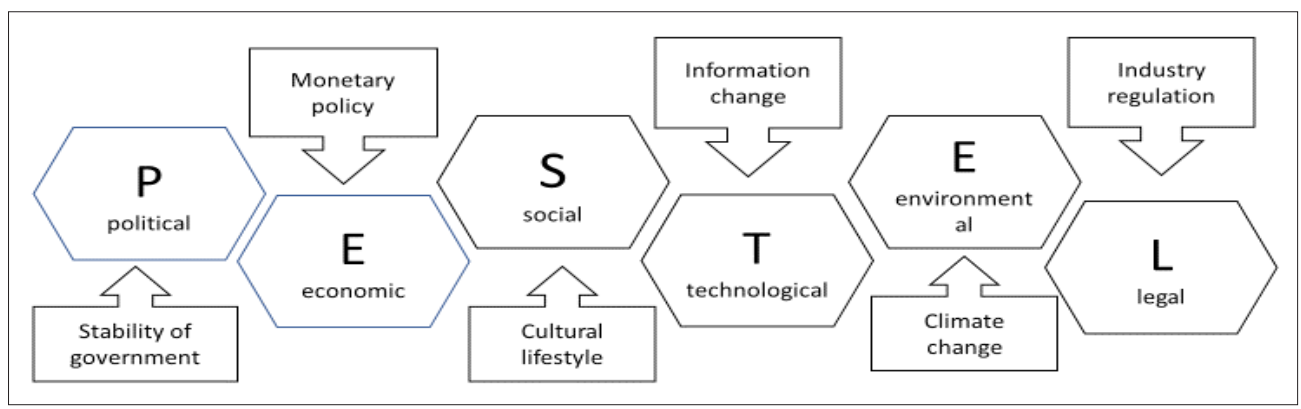

Figure 1. PESTEL Model and Its Representative Factor (by author) 
(born between 1946 and 1964); Generation X (1965-1980), Millennials (1981-1994); and Gen Z (1995-2012), according to Tweng (2017). Since there has been little research about Gen $Z$ in accordance with the new generation of Ok Boomers, this study selects the PESTEL model to investigate the macro-economic factors of emergence of the Ok Boomer generation.

\section{Application of PESTEL Model \\ to the Emergence of Ok Boomer on TikTok}

The first step in analyzing the emergence of Ok Boomers on TikTok and their influence on business from a marketing perspective is to focus on the external conditions that affect business operations, including the comprehensive business climate of contemporary trends in the U.S. and global markets. Although the PESTEL model has been criticized for its theoretical weakness of conceptualization, it serves as the guidance for empowering marketers to objectively evaluate where their companies can position themselves in a dynamic business environment (Nandonde, 2019). In addition, the model enables them to build strategies and implement tactics, which are the pivotal process of survival. The PESTEL model guides this article to illustrate the emergence of Ok Boomers, analyze the impact of Ok Boomers, and predict the prominence of the Ok Boomer generation in the near future for society and business. More importantly, this article shows why organizations, whether for-profit or non-profit, should stay current or keep up with issues of the Ok Boomer generation and TikTok, which demonstrate the capacity of shifting business operations from fulfilling the needs of the generations of Baby Boomer and Generation X to those of millennials and Gen Z. For this article, the PESTEL model is applied to elaborate on the factors of new power of Ok Boomer and TikTok.

\section{Political Factor of Ok Boomer and TikTok}

A government has the power of influencing the whole national economy and certain industries through political interventions. The Baby Boomer generation has become blessed beneficiaries of U.S. federal government interventions for the public after President Franklin D. Roosevelt established Social Security and President Lyndon B. Johnson enacted Medicare for people who are 65 years old or older, and Medicaid for the poor. In addition, the mortgage-interest deduction allows American homeowners to claim a tax break. According to Statista.com (2019), 78 percent of Americans aged 65 and older owned their home in 2019. It is a fact that baby boomers enjoy such government-organized benefits regarded as the vehicle for cementing old people's welfare and richness at the cost of younger people's deprived opportunity for a better life. The Baby Boomer generation's dominance on the structural changes in economy and politics for themselves results in rising 
price tags of healthcare, education, and homeownership, in which young people can hardly afford nowadays even with college degrees. Whereas the Ok Boomer generation has been going through the hardship of landing a decent job that is once regarded as the traditional steppingstone toward having a decent life or American dream, baby boomers collect fat Social Security checks and spend free time living in an experiential paradise - cruising the globe and contemplating buying a second home with their financial security. The older generation still shows no sign of political retirement as the U.S. government policies have been heavily affected by Donald Trump, Joe Biden, Mike Bloomberg, Nancy Pelosi, Bernie Sanders and Mitch McConnell, who are between 75 and 80 years old. The older or Baby Boomer generation's long-time prosperity was confirmed by Myrna Blyth, 80, senior vice president at AARP (formerly the Association of American Retired Persons), saying, "We're the people that actually have all the money" in her interview with a magazine in November 2019 (Pesce, 2019, para. 5). Blyth made the comment to mock the Ok Boomer generation's demands for creating fair and better government policies for all generations. Blyth's remarks were in part of the response to a meme on TikTok on October 15, 2019, that ridiculed baby boomers' advice for the Ok Boomer generation.

Baby boomers have benefited from the privileged system of U.S. federal policies, which are dubbed boomer socialism. They have money and power. This is what makes Ok Boomers worried about their future and feel hostile toward the Baby Boomer generation. Ok Boomers think that old people have failed to protect the interests of younger generations who struggle to match the living standards of older generations regarding housing, jobs, and retirement funds because of excessive rents, low wages, and their increasing tax burden. The younger generation realizes that it is still baby boomers calling the shots on important governmental policies, but they are unlikely to address decades of disparity for the climate change, unfair wage policies, and distorted economic structures that lead to a heavy weight to bear for Ok Boomers. As more baby boomers are retiring, the Ok Boomer generation is expected to foot the hefty bill of social costs. Such policies for boomer socialism are scrutinized by the Ok Boomer generation, and they are calling for a possible expansion of the existing social contract for their future. Another pivotal phenomenon that encourages the Ok Boomer generation to seek a political revolution is that the generational wealth gap has reached historic proportions: millennials despite having college degrees earn up to $41 \%$ less than baby boomers did at the same stage of life (Leonhard, 2019). Since the current policies of boomer socialism are unable to fix fewer job opportunities, higher college tuition debt, and lower wages for Ok Boomers, young people express their animosity toward the Baby Boomer generation via social media platforms in the form of mockery meme videos. TikTok has turned into the young generation's online playground for venting their rage and despair, especially young Americans who are establishing 
political coalitions through TikTok, because the social media platform allows users to transform "politics into comedy" and to have "someone their age talking like they're a friend" (Lorenz, 2020, para. 2-5) In sum, the major political factor is that the U.S. Federal policies of boomer socialism have resulted in creating the advent of Ok Boomers via the specific social media platform: TikTok.

\section{Economic Factor of Ok Boomer and TikTok}

Since Donald Trump took the oath of office as the President of the United States in 2017, he focuses on creating domestic manufacturing jobs. His economic policies worked well as the unemployment rate dropped to its lowest level for more than 49 years in April 2019. As part of his job creation plans, President Trump also declared trade war against China, accusing the Asian country of unfair trading practices and intellectual property theft. President Trump has imposed sweeping tariffs on Chinese products, worthy of $\$ 550$ billion dollars; China in return has set tariffs on U.S. goods, worthy of $\$ 185$ billion dollars in the period of 18 months (Shira, 2020). After the long trade war, the Chinese government agreed to root out intellectual property theft and increase technology transparency while increasing Chinese purchases of U.S. goods in January 2020. According to the Bureau of Economic Analysis of the United States Department of Commerce, real U.S. GDP grew 2.3 percent over the four quarters of 2019 with steady gains of consumer spending and residential investment, which proved the U.S. economy remains resiliently expansive. Although the U.S. economy indicates its strong growth, economic inequality widens because the top-earning $20 \%$ of U.S. households brought in $52 \%$ of all U.S. income, in which the Gini coefficient indicates the United States as the highest income inequality nation among the G7 nations (Schaeffer, 2020). More important, Business Insider reported in 2019 that the wealth gap between generations had nearly doubled in the past 20 years as millennials earned $20 \%$ less than baby boomers did at their age (Hoffower, 2019). As a result, the younger generation financially struggle with rising living and housing costs, increasing student-loan and credit card debt, and "the ongoing fallout of the recession" (2019, para. 8).

The Baby Boomer generation takes big advantage of lower interest rates. Because of the interest rates plunge to lowest in nearly 4 years since 2016, Timiraos (2020) reported that American homeowners' refinance applications hit the highest level in March 2020 since June 2013 (mortgage rates fluctuated, based on long-term bond rates). Homeowners who are able to refinance an existing mortgage are winners, including those who have an outstanding balance on their cards and can invest in stock and bond markets. Most of the beneficiaries of the lower interest rates belong to the group of baby boomers. On the other hand, the feelings of destitution embrace younger Americans, who remain marginalized from such economic advantages. What they have is an affordability crisis for their future. According to the Stanford Center on Poverty and Inequality, college students are "canaries in the 
coalmine" for toxic economic trends that systemically make them earn less money but die prematurely more from suicide or drug overdose than previous generations (Shashkevich, 2019). It is worth noting that the Baby Boomer generation was seen as greedy in the view of the Ok Boomer generation. While older people refuse to retire, younger people have trouble getting decent jobs with college degrees that lead them to the vicious struggle of paying off student loan debt of \$1.6 trillion, which is the second highest consumer debt category - behind only mortgage debt in the United States (Friedman, 2020). In fact, the Ok Boomer generation can barely share a fair amount of the strong economic factors such as economic growth, low interest rates, high disposable income of consumers and low unemployment rates. This is why the young generation reveals their disappointment or even antagonism toward the privileged old generation in a form of humorous mockery on TikTok, rather than expressing their hostile emotions in violent protest or demonstration on the street.

\section{Social Factor of Ok Boomer and TikTok}

With exclusive support from young Democrats under 30, Senator Bernie Sanders was rising in the early Democratic primary polls, conducted throughout February 2020. The 78-year-old, self-described socialist's popularity originates from his career advocacy for universal healthcare, free college tuition, and climate change fight. For young Americans, the democratic socialist's activism is directly related to the possibility of solving social problems they are facing now and future. The young generation is scared of the traditional or normative social environment where their lives can suffer a worse future than their parents have, due to the social conflicts of age distribution, income distribution, social barriers, and lifestyle attitudes. Such conflicts also originate from the distorted modern American capitalism, which molds the social structure into supporting boomer socialism. As the Baby Boomer generation has become the most financially and socially secure generation in American history, more young Americans are drawn into the messages of Sanders who promises progressive reforms for younger people. Ok Boomers think that the social safety net of the United States revolves around the beneficiaries of Social Security, Medicare, and housing subsidies. Rather than including them, the safety net works to push the young generation out of social benefits. In other words, Ok Boomers are engulfed by the fearful emotions of being ostracized and marginalized from the social safety net.

What young Americans genuinely seek is a system of social fairness that allows them to have equal social opportunities while expecting to widen the reach of government benefits for themselves. They recognize the disappearance of social steppingstones toward a life of prosperity as the social barriers of success for the young generation is getting higher. The opportunity of living, working and playing anywhere they want has dwindled in the American society because "higher 
education, affordable housing and quality healthcare" is out of reach for many young Americans (Zeballos-Roig, 2020). Their social frustration is well absorbed into the policies of Sanders who would change the U.S. social structure noticeably with a much-expanded welfare state. He hopes that the society makes college education free for everybody, funds universal healthcare for all, and wipes out all fossil fueled power replaced by green energy. The Ok Boomer generation sees such hopes as social justice for all, in which wealthy businesses and old people should pay higher taxes to offer better social safety nets for idealistic young people who admire many parts of European social systems. Sanders consciously satisfies the idealistic requirements of young Americans who ask for tackling the affordability crisis in housing, health care, climate change and college tuition debt. In response, the Ok Boomer generation keeps showing their loyalty for Sanders with TikTok Sanders memes of "Yeah, good. OK." Ritzen (2020) argued that Sanders is the young person's 2020 presidential candidate, so it's no surprise he has supporters on TikTok, beloved by OK Boomers who have the digital talent of transforming all types of social frustration into humorous TikTok memes.

\section{Technological Factor of Ok Boomer and TikTok}

Vermin Supreme, American performance artist, sees Ok Boomers as nonconformists who refuse to be boring adults; they use TikTok as the exclusive haven of online platform to express their angry feelings via humorous meme videos (Hood, 2020). The emergence of Ok Boomers cannot be discussed without TikTok. They are a perfect couple in the digital age. The social media world has been dominated by Facebook, Instagram, Twitter, Snapchat, YouTube, and LinkedIn in the past five years, but TikTok became the second most downloaded app in 2019, according to Forbes magazine, which also predicted the possibility of TikTok's taking over the U.S. market over Instagram from a marketing perspective (Forest, 2020). The term Ok Boomer exploded in late 2019 on TikTok with mocking memes via the short video format; so, what made TikTok popular to millennials and Generation Z? TikTok offers users the functions of 15-second clips of themselves "dancing, lip-syncing, doing comedy skits or participating in challenges that pop up on the platform" (Yurieff, 2020, para. 5). As younger people prefer watching to reading with less tolerance of boredom, TikTok's specialized platform for mocking memes in funny short visualization is well customized for the Ok Boomer generation. In other words, TikTok is a new online outlet for self-expressing young people, who would not mind sharing their silly, loud, and weird lifestyle. One of the biggest charms of TikTok is that it is an open site to goofiness and sense of genuine fun, as opposed to other popular social media platforms, which pressure users to have more followers and likes with filtered or staged posts of photos and videos. On TikTok users are free from the eyes of how they look to other people in the online world. 
Kory Marchisotto, chief marketer for e.l.f. Cosmetics, said in an interview with the Associate Press that TikTok is where the young party is, and "that's where they're all hanging out" (Arbel, 2020, para. 3). For the Ok Boomer generation, TikTok is more authentic than the self-consciously pretty and polished Instagram. Instagram users are for "photos that look nice, or the good things" they are doing, while TikTok users are to "get loose, make jokes, pull pranks and stuff, dress up weird" (Arbel, 2020, para. 11). As a result, $70 \%$ of TikTok users are age 14 to 26 , who make up $40 \%$ of all U.S. consumers in 2020. It is also projected to reach 60.3 million U.S. consumers, or about $27 \%$ of social network users, by 2024 , according to MobileMediaMarket.com (2020). Because of its explosive popularity, TikTok has been a threat to major social media platforms especially for Facebook, the most popular network worldwide as of January 2020, ranked by number of active accounts: for Facebook there are over 1 billion registered accounts (Hamilton, 2020). Since Facebook has been popularized as parents' online playground, American teens dumped the most popular online platform for Instagram and Snapchat, according to a 2018 study by Pew Research Center. Sheryl Sandberg, Facebook's COO, admitted that Facebook worries about the threat posed by TikTok, which has been growing quickly with bigger numbers faster than Facebook ever did (Hamilton, 2020) Snapchat CEO Evan Spiegel also predicted that "TikTok could overtake Instagram because it relies on talent rather than social posturing"(Hamilton, 2020, para. 6) Whether it was an innovation or a technological alteration, TikTok has been successfully offering a new social media paradigm for Ok Boomers, who know what is going on technology-wise in term of preferring more self-awareness of feeling-good authenticity to the public displays of wearing superficial social masks.

\section{Environmental Factor of Ok Boomer and TikTok}

What the Ok Boomer generation is most concerned about is climate change among many other issues for their present and future lives, including rising inequality, unaffordable college tuition, and political polarization. Some young news reporters even argue that climate change is the ultimate OK Boomer issue (Riederer, 2019). While the Ok Boomer generation blames baby boomers for the existing political, economic and social problems, the issue of climate change plays the lead role in waging the generational tension. Growing awareness of the potential impacts of climate change by Ok Boomers is affecting their fundamental survival instincts to deal with mosquito-borne diseases like malaria and dengue fever, Zika and Ebola virus as well as a rise in cases of chronic conditions like asthma from a direct link of global warming. In addition, Ok Boomers are concerned with an increase in extreme weather events of hurricanes and snowstorms since changes in climate can cause the thawing of ice, which can lead to rising sea levels. According to the United States Environmental Protection Agency, the climate change can create the combined impacts of drought, severe weather, landslides, lower groundwater reservation, and 
a loss of arable land with an army of pests' emergence (Environmental Protection Agency, 2020). As a result, food insecurity from severe crop failures and livestock shortages worldwide can be expected when Ok Boomers reach their 30s or 40s (Bradford, 2017). The 2016 outbreak of Zika virus, a mosquito-borne illness, also enlightened young Americans of the dangers of climate change.

The climate crisis fueled the Ok Boomer generation's anti-baby boomer sentiment. It is worth noting that two public figures sparked the climate change debate worldwide from each side: for Ok Boomers, Greta Thunberg, the Swedish teen activist who became the voice of a new emerging generation with a concern over climate change and was named Time magazine's 2019 Person of the Year; and for baby boomers, President Donald Trump who announced the 2019 U.S. withdrawal from the Paris Climate Agreement and was named Time magazine's 2016 Person of the Year. Climate crisis activist Thunberg, 17, gained international attention after condemning world leaders for their inaction in the climate crisis at the UN Climate Action Summit in September 2019. She urged the leaders to fight global warming, bluntly and angrily speaking, "We are at the beginning of a mass extinction and all you can talk about is money and fairy tales of endless economic growth. How dare you!" (Chasan, \& Wainer, 2019). Time magazine editor-in-chief Edward Felsenthal pointed out that her emotional speech led her to become "the biggest voice on the biggest issue facing the planet" (Flynn, 2019, para. 3). On behalf of the Baby Boomer generation, President Trump responded Thunberg's criticism by sarcastically tweeting: "She seems like a very happy young girl looking forward to a bright and wonderful future. So nice to see!” (Trump's Tweet account, available at https://twitter.com/realdonaldtrump/status/11763395221136 79360 ?lang=en). The generational debate over climate change is visualized more by millions of fed-up kids' messages of climate change awareness through TikTok videos calling for people to save the Earth. Although the Ok boomer generation is anxious about the future, they are not going disorientated for their future. They get involved in environmental advocacy on TikTok by entertaining and engaging with people in hopes of gaining momentum for their environmental activism, which targets most 13 to 18-year-olds who are unlikely to always watch the news (Bogle, 2019). Ok Boomers capitalize on TikTok memes to tackle and raise awareness of the biggest issue of their livelihood, the climate change. Such TikTok memes seem designed to be humorous, but they appear fundamentally satirical to urge people to "think more deeply about how that humour is being caused or being formed" (2019, para. 23).

\section{Legal Factor of Ok Boomer and TikTok}

Ok Boomers and TikTok deal with their own separate legal issues. For Ok Boomers, discrimination laws are discussed in the public sphere. While the term Ok Boomer as a noun cluster went viral on TikTok and implied a mocking dismissal 
of older generations in late 2019, the term entered human resources departments of corporate organizations in case employees started saying "Ok Boomer" at work. Since the term can be interpreted offensive to baby boomers with the matter of age discrimination, it can extend to a certain level of an age-related insult. According to U.S. Department of Labor of the United States, the Age Discrimination in Employment Act of 1967 protects workers at least 40 years of age and older from discrimination on the basis of age in hiring, promotion, discharge, compensation, or terms, conditions or privileges of employment. Based on the Act, comments about layoff or blocked promotion that relate to a worker's old age inside an organization can be considered age discrimination. Elizabeth C. Tippett (2019), an associate professor at the University of Oregon School of Law, hypothetically exemplifies an Ok Boomer legal situation:

"If a manager said "Ok Boomer" to an older worker's presentation at a meeting, that would make management seem biased. Even if that manager simply tolerated a joke made by someone else, it would suggest the boss was in on it" (para.7)

The matter of legality for the term Ok Boomer even reached the Supreme Court of the United States where Chief Justice John Roberts asked if the phrase would count as age discrimination in January 2020. During oral arguments in the case Babb v. Wilkie, Roberts said, "So calling somebody a 'boomer' and considering them for a position would be actionable?" In response, one of the lawyers in court compared the term OK Boomer to "saying unflattering things" about a person, arguing that "in a hiring process, it could indeed indicate discrimination" due to the term's derogatory implication against older people (BBC News, 2020, para. 8).

TikTok also confronts legal challenges. The platform's parent company is Chinese tech giant, ByteDance. Technically, TikTok is a Chinese company. Hence, U.S. lawmakers are concerned about misgivings of TikTok that can be exploited by the Chinese government, infamous for its wielding power to extract foreign data from all Chinese companies abroad. Steve Huffman, Reddit CEO, even identified TikTok as Chinese "spyware" (Hamilton, 2020). Because of its Chinese nationality, the U.S. Transportation Security Administration banned employees from using TikTok to post videos in the matter of national security. The bigger popularity TikTok, the more legal challenges TikTok seems bound to deal, especially with censorship, data privacy and brand safety (Doffman, 2020). As a consequence, U.S. lawmakers in October 2019 called for a national security probe into TikTok, expressing concerns about the platform's collection of user data and its censored content by the Chinese government. In response, the U.S. government launched a national security review of TikTok, and the review by the government is still an ongoing process. 


\section{Discussion}

Ok Boomers are social media savvy. They seek authenticity and positive rolemodels on TikTok. Millennials and Gen-Z account for $64 \%$ of the world's entire population, approximately 4.7 billion people; Gen Z itself makes up $40 \%$ of all U.S. active consumers in 2020; and 75\% of U.S. consumers aged between 13 and 34 are spending multiple hours a day on image-messaging apps (Forest, 2020). From a public relations perspective, TikTok has great potential for brands to develop their marketing channel and to follow emerging trends. For example, young people spend several hours on TikTok entertaining themselves with new dance moves and humorous parodies about social and political issues. Brands can leverage TikTok to collaborate with authentic content creators in pursuit of promoting their products or services. TikTok, based on its popularity and growth projection, seems to have an ability of playing an important role in transforming the influencer marketing systems from the posts of heavily filtered images to those of authentically humorous meme videos. As the Ok Boomer generation is more conscious about social, political, and environmental issues for their future, brands need to resonate with the physical and psychological needs of young people who value corporate images and reputations. Public relations practices of corporate social responsibility (CSR) and sustainability can be a good start to gain the psychological trust of the generation. To meet the physical needs, brands should commit on a new approach to partnering with TikTok's Hype House group mansion in Los Angeles, where TikTok creators distributes their authentic content, as opposed to the perfect, overedited content created by superficial and polished influencers.

This article analyzed the emergence of Ok Boomers and their favorite social media platform, TikTok from the viewpoints of public relations management and marketing. Departing from the PESTEL model, this article explained some unique characteristics of the Ok Boomer generation and described their attitudes toward society and other generations, based on the macro-environmental (external business environment) factors. As the right PR and marketing strategy leads brands to achieve goals and grab a competitive advantage, this article's PESTEL analysis on the Ok Boomer generation as a new target audience and TikTok as a dominant social media platform can be used to gain an extensive understanding of the macroeconomy trends of 2020.

This article comes with two limitations: One is its lack of empirical data on TikTok since the social media platform became overnight sensation; however, as more TikTok data used by the young generation have been amassed, more empirical analyses of TikTok are expected such as Facebook and Twitter in the future. The other is linked to a still-developing process of the Ok Boomer's conceptualization, which should bring a generalizable identification to the new generation. Therefore, future research can focus on improving the two phenomena's impacts on social and cultural relations. 


\section{References}

1. Arbel, T. (2020, February 29). Teens love the video app TikTok. Do they love it too much?, The Associated Press. Retrieved on March 15, 2020 from https://apnews.com/2d30 64d67b71aad7ea35793f16109fae.

2. BBC News (2020, January 16). OK Boomer': From TikTok meme to the US Supreme Court, $B B C$. Retrieved on January 25, 2020 from https://www.bbc.com/news/world-uscanada-51132554.

3. Bogle, A. (2019, September 19). Students are fighting climate change, one TikTok video at a time, $A B C$ News. https://www.abc.net.au/news/2019-09-19/tiktok-youth-led-climateactivism-school-strike/11520474.

4. Bradford, A. (2017). Effects of Global Warming, LiveScience, https://www.livescience. com/37057-global-warming-effects.html.

5. Chasan, E. \& Wainer, D. (2019, September 23). Teen Activist Greta Thunberg to World Leaders: 'How Dare You!', Bloomberg. Retrieved on January 29, 2020 from https:// www.bloomberg.com/news/articles/2019-09-23/teen-activist-greta-thunberg-to-worldleaders-how-dare-you.

6. Dimock, M. (2019). Defining generations: Where Millennials end and Generation Z begins, Pew Research Center. https://www.pewresearch.org/fact-tank/2019/01/17/whe re-millennials-end-and-generation-z-begins/.

7. Dictionary.com (2020). Ok boomer. https:/www.dictionary.com/e/slang/ok-boomer/.

8. Doffman, Z. (2020, April 13). TikTok Users Beware: This Is How Hackers Can Send Dangerous Videos to Your iPhone Or Android. Forbes. Retrieved on April 27, 2020 from https://www.forbes.com/sites/zakdoffman/2020/04/13/tiktok-users-beware-this-is-howhackers-can-swap-your-videos-for-dangerous-fakes/\#63531e1e3cc8.

9. Environmental Protection Agency (2020). Climate Change Research. https://www.epa. gov/climate-research.

10. Flynn, K. (2019, December 11). Time Person of the Year: Climate crisis activist Greta Thunberg, CNN. Retrieved on March 4, 2020 from https://www.cnn.com/2019/12/11/ media/time-person-of-the-year-2019/index.html.

11. Forest, A. (2020, February 26). TikTok Versus Instagram: Is This Chinese App Taking Over The U.S. Market?, Forbes. https://www.forbes.com/sites/forbesagencycouncil/2020/ 02/26/tiktok-versus-instagram-is-this-chinese-app-taking-over-the-u-s-market/\#6cd334 $015 \mathrm{~d} 98$.

12. Friedman, J. (2020, February 3). Student Loan Debt Statistics In 2020: A Record $\$ 1.6$ Trillion, Forbes. Retrieved on March 21, 2020 from https://www.forbes.com/sites/zack friedman/2020/02/03/student-loan-debt-statistics/\#6f365671281f.

13. Hamilton, I. (2020, February 27). Sheryl Sandberg said she worries about TikTok because it got huge faster than Facebook did, Business Insider, Retrieved on April 2, 2020 from https://www.businessinsider.com/sheryl-sandberg-said-she-worries-abouttiktok-2020-2.

14. Hassan, Z., Jailani, M., \& Rahim, F. (2014). Assessing the Situational Analysis of Heritage Tourism Industry in Melaka. Procedia - Social and Behavioral Sciences, 130(C), 28-36. https://doi.org/10.1016/j.sbspro.2014.04.004. 
15. Hoffower, H. (2019, August 6). The wealth gap between generations in the US has nearly doubled in the past 20 years, Business Insider. Retrieved on February 13, 2020 from https://www.businessinsider.com/millennials-net-worth-versus-baby-boomers-gen erational-wealth-gap-2019-8.

16. Hood, A. (2020, February 2). OK boomer - middle-aged adults are gaining millions of followers on TikTok, proving the app isn't just for Gen Z, Insider. Retrieved on March 30, 2020 from https://www.insider.com/ok-boomer-adults-on-tiktok-app-vermin-supremegen-z-2020-2.

17. Kenton, W. (2020). 'PEST Analysis', Investopia. https://www.investopedia.com/terms/p/ pest-analysis.asp.

18. Leonhardt, M. (2019, November 5). Millennials earn $20 \%$ less than baby boomers diddespite being better educated, CNBC, available at https://www.cnbc.com/2019/11/05/ millennials-earn-20-percent-less-than-boomersdespite-being-better-educated.html.

19. Lorenz, T. (2020, February 27). The Political Pundits of the Future Are on TikTok, The New York Times. Retrieved on March 29, 2020 from https://www.nytimes.com/2020/02/27/ style/tiktok-politics-bernie-trump.html.

20. MobileMediaMarket. (2020). TikTok to grow $22 \%$ to $45 \mathrm{M}$ US users this year, eMarketer says, https://www.mobilemarketer.com/news/tiktok-to-grow-22-to-45m-us-users-thisyear-emarketer-says/573187/.

21. Nandonde, F. (2019). A PESTLE analysis of international retailing in the East African Community. Global Business and Organizational Excellence, 38(4), 54-61. https://doi.or $\mathrm{g} / 10.1002 /$ joe.21935.

22. Njinyah, S. (2018). The effectiveness of government policies for export promotion on the export performance of SMEs Cocoa exporters in Cameroon. International Marketing Review, 35(1), 164-185. https://doi.org/10.1108/IMR-05-2016-0103.

23. Pesce, N. (2019, November 13). AARP exec: 'OK, millennials .... we're the people that actually have the money', MarketWatch, https://www.marketwatch.com/story/aarpexec-ok-millennials-were-the-people-that-actually-have-the-money-2019-11-13.

24. Pew Research Center (2018). Teens, Social Media \& Technology 2018, https://www. pewresearch.org/internet/2018/05/31/teens-social-media-technology-2018/.

25. Riederer, R. (2019, December 9). Climate Change Is the Ultimate "OK, Boomer" Issue, The New Republic. Retrieved on February 5, 2020 from https://newrepublic.com/article/ 155905/climate-change-ultimate-ok-boomer-issue.

26. Ritzen, S. (2020, January 22). 'Yeah, good. OK' Bernie Sanders meme is a new way to dismiss people, Daily Dot. Retrieved on March 19, 2020 from https://www.dailydot.com/ unclick/yeah-good-ok-bernie-sanders-meme/.

27. Roberts, M. (2019, November 5). OK, boomer. The kids are fighting back, The Washington Post. Retrieved on January 28, 2020 from https://www.washingtonpost.com/opinions/ ok-boomer-the-kids-are-fighting-back/2019/11/05/32894688-0011-11ea-9518-1e76abc0 88b6_story.html.

28. Sanders, R. (2011). (Im)plausible legality: the rationalisation of human rights abuses in the American "Global War on Terror." The International fournal of Human Rights: 
American Democracy, Promotion and Obama, 15(4), 605-626. https://doi.org/10.1080/13 642987.2011.561991.

29. Schaeffer, K. (2020). 6 facts about economic inequality in the U.S., Pew Research Center. https://www.pewresearch.org/fact-tank/2020/02/07/6-facts-about-economic-inequalityin-the-u-s/.

30. Shashkevich, A. (2019, June 6). Millennials are 'canaries in the coalmine' for toxic economic trends, say Stanford scholars. Stanford News. Retrieved on March 30, 2020 from https://news.stanford.edu/2019/06/06/toxic-economic-trends-impacted-millennials/.

31. Shira, D. \& Associates (2020). The US-China Trade War: A Timeline, available at https:// www.china-briefing.com/news/the-us-china-trade-war-a-timeline/.

32. Shiu, E., Hassan, L., \& Walsh, G. (2009). Demarketing tobacco through governmental policies - The 4Ps revisited. (Report). Journal of Business Research, 62(2), 269-278. https:// doi.org/10.1016/j.jbusres.2008.01.034.

33. Song, J., Sun, Y., \& Jin, L. (2017). PESTEL analysis of the development of the waste-toenergy incineration industry in China. Renewable and Sustainable Energy Reviews, 80, 276-289. https://doi.org/10.1016/j.rser.2017.05.066.

34. Statistica Online (2019). Homeownership rate in the United States as of Q2 2019, by age, https://www.statista.com/statistics/1036066/homeownership-rate-by-age-usa/.

35. Stuiver M, Soma K, Koundouri P, et al. (2016). 'The governance of Multi-Use Platforms at Sea for energy production and aquaculture: challenges for policy makers in European seas', Sustainability, 8(4), 333.

36. Timiraos, N. (2020, March 3). Federal Reserve Cuts Rates by Half Percentage Point to Combat Virus Fear, The Wall Street fournal. Retrieved on April 2, 2020 from https:// www.wsj.com/articles/federal-reserve-cuts-interest-rates-by-half-percentage-point-115 83247606.

37. Tippett, E. (2019, November 21). Why saying "OK, boomer" at work can be age discrimination, CBS News. Retrieved on January 12, 2020 from https://www.cbsnews. com/news/why-saying-ok-boomer-at-work-can-be-age-discrimination/.

38. Tweng, J. (2017). ‘iGen: Why Today's Super-Connected Kids Are Growing Up Less Rebellious, More Tolerant, Less Happy', Atria Books ( $2^{\text {nd }}$ edition). U.S. Department of Labor (n.a.). Age Discrimination, available at https://www.dol.gov/general/topic/ discrimination/agedisc.

39. Wiersum, K., Lescuyer, G., Nketiah, K., Wit, M., \& Wiersum, K. (2013). International forest governance regimes: Reconciling concerns on timber legality and forest-based livelihoods. Forest Policy and Economics, 32, 1-5. http://search.proquest.com/docview/144 3375226/.

40. Yurieff, K. (2020, February 19). TikTok, every teenager's favorite app, just rolled out new parental controls, CNN. Retrieved on February 27, 2020 from https:/www.cnn. com/2020/02/19/tech/tiktok-parental-controls/index.html (accessed 1th March, 2020).

41. Zeballos-Roig, J. (2020, February 16). Young adults support Bernie Sanders because they want to benefit from 'boomer socialism' that older Americans already enjoy, Business Insider. Retrieved on April 2, 2020 from https://markets.businessinsider.com/ news/stocks/younger-americans-benefit-boomer-socialism-support-bernie-sanderscapitalism-reason-2020-2-1028908562. 